\title{
Suulisus ja kirjalikkus allikapärimuses Taevaskoja Emalätte näitel ${ }^{1}$
}

\author{
Kristel Vilbaste \\ Tallinna Ülikooli humanitaarteaduste instituudi doktorant \\ kristel.vilbaste@gmail.com \\ Mikk Sarv \\ rahvaluuleteadlane, haridusteaduse magister \\ mikk@ilm.ee
}

\begin{abstract}
Teesid: Taevaskoja Emaläte on üks tuntumaid allikaid Eestis. Kirjapandud pärimuse vähesus põhjustas määramatuse pärast 2013. aastal toimunud allikakoopa varingut. Küsitlesime erineva kogukondliku ja pärimusliku taustaga inimesi poolstruktureeritud intervjuu meetodil, uurides, kellele kuulub pühapaik ja kes on pädev otsustama maastiku korrastamise üle. Intervjuudest selgus, et inimesed, kes elasid kohapeal ja tundsid suulist pärimust, soovisid allika kiiret taastamist endisel kujul. Inimesed, kelle igapäevavajadused ei olnud vahetult Emalättega seotud, eelistasid varingu jätmist looduslikule taastumisele. Seejuures lähtusid nad teiste pühapaikade kohta kirjutatust, kus keelatakse sakraalsel objektil igasugune inimese sekkumine. Kirjalikkus kujundab vahendatud suhtumise, mis väldib otsustamisega vastutuse võtmist. Pärimuse suulisus väljendab vahetut ja aktiivset suhet ning valmidust otsustava tegutsemisega vastutuse võtmist pühapaiga jätkusuutlikkuse nimel. Rahvusvahelise Looduskaitseliidu (IUCN) looduslike pühapaikade kaitse juhendi järgi otsustavad paiga staatuse üle selle eestkostjad, kelleks sobivad praeguste seaduslike ja kirjasõnast lähtuvate seaduslike valdajate asemel kohaliku kogukonna esindajad, vahetu suulise pärimuse kandjad.
\end{abstract}

Märksõnad: allikapärimus, maastikudiskursus, maastikumälu, pühapaiga taasväärtustamine, Taevaskoja Emaläte

\section{Sissejuhatus}

Käesolevas artiklis püstitasime tööhüpoteesi, et suuline pärimus on keskkonnateadlikkuse representeerimisel reaalsituatsioonis efektiivsema toimega kui kirjalik pärimus. Selle kontrollimiseks pakkus võimaluse Taevaskoja Emalätte laialdast poleemikat tekitanud varing 27. juunil 2013. aastal ning sellele järgne- 
nud diskussioon, kas ja kuidas varingu tagajärgi likvideerida, respekteerides loodusliku pühapaigaga seotud traditsioone ning erinevaid kasutajaid ja huvirühmi.

Artikkel kirjeldab lühidalt pühapaikadeks nimetatud allikate problemaatikat. Anname ülevaate Taevaskoja Emalätte sissevarisemise juhtumi uurimise metoodikast ja käsitleme Emalättega seotud kirjalikke teateid. Samuti vaatleme, milline on olnud Emalätte staatus ja lähiajalugu. Edasi käsitleme intervjuude põhjal ilmnenud suhtumisi allikasse ja otsime vastust küsimusele, kuidas mõjutab pärimuse tundmine maastikuobjekti hoidu.

Maastiku ja pärimuse suhte uurimine on tänapäeva Eestis üks trenditeemasid, millega tegeleb palju huvirühmi, kes koguvad suulist ajalugu, kohapärimust, väärtustavad ja publitseerivad kohapärimust kajastavaid tekste, tegelevad omausu (taas)elustamise ja palju muuga (Kõivupuu 2014). Mingi maastiku kujunemine religioosseks ja ajaloolist mälu kandvaks paigaks sünnib peamiselt nimetamise, jutustamise ja konkreetse märgistamise kaudu ning suures osas suulise traditsiooni edasikandumise toel (Siikala 2004).

Taevaskoda on üks Eesti olulisematest pühapaikadest, ta on erinevate maastikuobjektide kogum: seal on allikas, ohvrikivi, põlispuud ja jõgi, kuid looduslikuks pühapaigaks teeb ta nendele maastikuobjektidele lisanduv inimlik aspekt, mis avaldub pärimuslugudes. Kuigi looduslikud pühapaigad on maastikul kõigile kättesaadavad, seisneb nende peamine väärtus vaimses kultuuripärandis ning sellega haakuvas rahvuslikus identiteedis ja ühiskondlikes sidemetes.

Looduslike pühapaikadega seotud ajaloolise mälu kõige teaberikkamaks hoidjaks on rahvapärimus. Folkloristide arvates kannab Eesti hiiepärimus tõenäoliselt tuhandeid aastaid vanu ladestusi, suuliselt on seda edasi kantud aastasadu, kuid viimase 150 aasta informatsioon on kohapärimuse kogumise käigus salvestatud ja arhiveeritud.

Rahvusvahelise Looduskaitseliidu looduslike pühapaikade juhend (Wild \& McLeod 2008) nimetab looduslikeks pühapaikadeks kohti, kus on tähenduslikus kokkupuutes loodus, side ülejäänud maailmaga, isiklik ja kollektiivne mälu. Looduslikel pühapaikadel võib olla ka ajaloo, kultuuri ja puhkamisvõimalustega seotud ilmalik väärtus. Looduslikud pühapaigad võivad olla olulised kultuuriidentiteedi kinnitajad perekonnale, sugukonnale, hõimule, teatud usu järgijatele või kogu rahvale, kelle identiteet on seotud konkreetse paigaga looduses. Paljudes ühiskondades täidavad looduslikud pühapaigad ametlike kaitsealadega sama ülesannet. Nendele paikadele omistatud vaimsetest väärtustest tulenevad sageli juurdepääsu- ja kasutuspiirangud ning paljud sellised kohad on looduslikus või looduslähedases seisundis.

Teistest looduslikest pühapaikadest eristuvad kõige enam veekogud, mis on meie maastikele väga iseloomulikud ja olulised, nad on mälumaastikud, mille domineerivaim element on vesi. Vesi on inimeste eksisteerimiseks olnud 
vajalik läbi aegade, algsed inimasulad tekkisid eelkõige veekogude äärde. Vesi on tähtis, nii on ka veest jutustav pärimus rikkalik ja mitmekesine - selles tulevad ilmsiks eri piirkondade pärimusele iseloomulikud teemad ja rõhuasetused (Remmel 2014).

Teistest veekogudest eristuvad selgelt allikad. Selge ja puhta vee tõttu on neid peetud pühaks, nende folkloor eristub teiste veekogude folkloorist mõningal määral (Rattue 2001). Peamiselt käsitletakse veekogusid puudutavates artiklites ja kogumikes allikaid teiste veekogude hulgas, kuid nad erinevad kohapärimuse, keskkonnakaitse ja sakraalsuse poolest nii teistest looduslikest pühapaikadest kui ka teistest veega seotud pärimuslikest paikadest.

Kultuurigeograafia ühe rajaja Carl Ortwin Sauteri järgi annavad kultuurigeograafiliste uuringute põhialuse loodusgeograafilised teadmised maastiku morfoloogiast ja nende kohandamine inimese poolt muudetud maastikule ning antropoloogias kasutatava etnograafilise välitöö omavaheline sidumine (SooväliSepping 2016). 1990. aastate representatsioonikriis tõi kultuurigeograafiasse kultuurilise pöörde, geograafid avastasid enda jaoks, et kultuur pole üksnes ettearvamatute ja sõltumatute ühiskonda mõjutavate jõudude kogum, vaid viis, kuidas inimrühmad mingites sotsiaalsetes, majanduslikes ja poliitilistes oludes käituvad (Kaur \& Palang 2005). Maastik muutus kultuuripõhiseks mõisteks ja koos keelega hakkas geograafe huvitama teksti semiootiline mõtestamine.

Lihtsustatult võime tänapäeval kõnelda kahest maastikudiskursusest: ökoloogilisest ja semiootilisest (Cosgrove 2003). Väites, et maastikul on mälu, personifitseerib inimene maastikku ja maastik saab seeläbi inimeste suulise ja kirjutatud ajaloo lahutamatuks osaks (Kõivupuu 2014). Eestlaste maastikumälu on tunduvalt vähem monumentide külge kinnitunud kui lääne-eurooplastel (Kaljundi \& Sooväli-Sepping 2014). Siinsete maastiku mälupankadena saab eelkõige käsitleda looduslikke pühapaiku või loodusobjekte. Kuigi tänapäeval on kõikjal maailmas looduslikud pühapaigad kaotamas oma rolli religioossete objektidena, on rahva mälus ja arhiivides see osa püsivalt fikseeritud.

Allikad on omandanud kogu maailmas eelkõige religioosse tähenduse (Rattue 2001; Harte 2008), nad on kultusobjektid, kus viiakse läbi riitusi, eriti tugevalt on see tava säilinud katoliiklikes ja õigeusu maades. Samas on kõikjal maailmas sagenemas allikate kuivendamine kaevandamisel või ehitustegevusel ja seetõttu ka allikate hävitamine, mis toob omakorda kaasa vastuseisu kohalike kogukondadega. Allikate roll keskkonnateadlikkuse väljendajana hakkas Eestis domineerima 1980. aastatel "fosforiidisõja" ajal. Need on omandanud tähtsuse looduslike pühapaikadena.

Eestis on paarkümmend koopaallikat, mis on olnud olulised kohalikule kogukonnale kooskäimiseks, usulisteks riitusteks ja pelgupaikadeks (Tamla 1985; Heinsalu 1987; Vilbaste 2013), nende koopaallikate kohta on arhiveeritud 
hulgaliselt muistendeid ja pärimusteateid. Tuntuimad on Taevaskoja Emaläte, Tilleoru Merioone, Hennu Raudläte, Aageoru läte, Tori Põrgu, Maimu koobas, Helme Arstle allikas, Allikukivi koobas, Karksi allik, Koodioru Põrgu, Loodi Põrgu jt. Nimetatud allikad asuvad devoni punases liivakivis ning on suureneva turismikoormuse ja looduslike tingimuste halvenemise korral varisemisohtlikud. Mitmete liivakivikoobaste puhul on näha lisaks allika uuristamistoimele ka inimtekkelisust, osad on toestatud, suletud trellide või uksega, mõnel on koguni restaureeritud koopalagi (Heinsalu 1987; Vilbaste 2013).

Koobaste varingud kajastuvad kaude allikapärimuses, keelud ja keskkonnahoidlikkus on kandunud suust suhu kohalike inimeste lugudes. Vee puhtuse tagamine ja allikate puhastamise nõue kajastub allikapärimuses nii meil kui ka kogu Euroopas (Bord 2006; Svensson 2012).

Allikakoobaste sissevarisemise järel allakukkunud liiva eemaldamine ja koopalae taastamise parimaks näiteks on Allikukivi koopa taastamine eelmise sajandi lõpus (Vilbaste 2013), samas on sellised vanad kultuspaigad nagu Tori Põrgu, Karksi allik, Maimu allik ja Mäletjärve Silmaläte kaotanud omaaegse kuulsuse, neid kohti on võõral ja sageli ka kohalikul inimesel raske isegi üles leida, rääkimata nende sihtotstarbelisest kasutamisest.

\section{Uurimismetoodika}

Uurisime Taevaskoja Emalätte näitel aastal 2013 allikakoopa kokkuvarisemise järel tekkinud diskussiooni osapoolte põhjendusi, kuidas oleks olnud õige koopa sissevarisemise järel käituda.

Uurimisküsimuseks oli, kes on pädev otsustama pühapaiga taasväärtustamise üle ja kuidas pühapaika hoida?

Emalätte koopa kokkuvarisemise järel viisime läbi juhtumiuuringu. Kohapärimuse kameraalanalüüsil töötasime arhiiviteadetes läbi Taevaskoja Emalätte ja ka Taevaskojaga seotud Võnnu kihelkonna pärimusteated Eesti Kirjandusmuuseumi rahvaluule arhiivis, samuti Taevaskoda puudutavad aja- ja kultuurilugu ning keskkonnahoidu puudutavad trükised, perioodika ja elektroonsed andmebaasid. 20. sajandi alguseni olid leitavad vaid kohapärimusteated, 1920. aastatest alates leiab teateid ja pikemaid kirjeldusi ka ajakirjanduses ja ilukirjanduses, siiski oli ootamatu informatsiooni vähesus, see suurenes alles Taevaskoja kujunemisel turismipaigaks. Kogusime kokku olemasoleva taustamaterjali koopaallika kohta, otsides informatsiooni, kuidas on kirjalik pärimus mõjutanud inimeste suhtumist allikasse.

Välitöödel hindasime Emalätte olukorda alates allika sissevarisemisest 2013. aasta juunist viiel korral. Osalusvaatluse käigus jälgisime diskussiooni, 
mis toimus ajakirjanduses ja koosolekutel. Kahel korral avaldasime Taevaskoja Emalätte taastamisvõimaluste kohta olemasolevat informatsiooni kasutades arvamust Eesti ajakirjanduses, tele- ja raadioesinemised on fikseeritud ka veebiportaalides ${ }^{2}$.

2016. aasta sügisel viisime läbi viis poolstruktureeritud intervjuud, intervjueeritavate hankimiseks kasutasime välitöödel sotsioloogias kasutatavat nn lumepallimeetodit: isiklike kontaktide vahendatud võtmeisikud juhatasid meid järgmiste inimeste juurde, intervjueeritavate valikukriteeriumiks oli see, et nad olid oluliste huvirühmade esindajad, Taevaskoja Emalätte koopa taastamisega seotud või sel teemal sõna võtnud. Igaüks esindas erinevat arvamust Taevaskoja loodus- ja pärimushoiul. Töö käigus küsitleti veel antud probleemiga seotud inimesi, kuid nende arvamused olid sarnased intervjueeritud inimestega, seega ei oleks need andnud tööle lisaväärtust.

Kõigi intervjueeritavatega viidi läbi ühe tunni pikkune intervjuu, mil nad vastasid 16 küsimusele, mis olid jagatud viieks blokiks. Tekstid litereeriti ja vastuseid analüüsiti küsimuste kaupa. ${ }^{3}$

Ettevalmistatud küsimuste esimese bloki moodustasid küsimused, millega püüdsime välja selgitada intervjueeritava tausta ja Taevaskoja Emalättega seotuse põhjuseid ning selle paiga pärimuse tundmise allikaid ja mahtu.

Teises blokis küsisime teavet paiga turismipotentsiaali ja külastatavuse kohta, samuti seda, kui tihti intervjueeritav ise antud objekti külastab.

Kolmandas blokis keskendusime varingu põhjustele, uurisime, mis eelnes loodusliku pühapaiga katastroofile.

Neljandas selgitasime, millised olid pühapaiga taastamise üle puhkenud diskussiooni põhjused ja tagajärjed.

Viiendas uurisime loodusliku pühapaiga omandisuhet. Kellele kuulub pühapaik, seda nii erinevate usurühmituste, maakasutusvormide, kui ka keskkonnakaitse lõikes. Kellel peaks olema looduslike pühapaikade hooldamise õigus? Milline peaks olema Taevaskoja Emalätte taasväärtustamise tee ja mis on tema perspektiiv?

\section{Taevaskoja Emaläte maastikupärandi objektina kirjalikes allikates}

Nii kirjalikud allikad kui ka intervjueeritavad väidavad, et Taevaskoja kohta on väga vähe talletatud muistendeid. Olemasoleva kirjanduse analüüsimine ja arhiivimaterjalide uurimine kinnitab seda väidet. See on mõnevõrra üllatav Eestile nii olulise objekti puhul. Eerik Kumari kirjutab 1972. aastal: "Kuigi Emaläte on kohaliku rahva seas laialt tuntud, ei ole tema kohta teada ühtki 
muistendit. Arvatakse, et ta on Taevaskojas keskseks allikaks (emaks), mis toidab kõiki teisi, ja sellest on tulnud ka ta nimi" (Kumari 1972: 20). Ka internetiotsing Google'i keskkonnas annab otsisõnale "Emaläte" vaid 2640 vastet, suurem osa neist kirjeldavad just varingujärgset problemaatikat.

Kohapärimusteated on laiali arhiivides ja raamatutes, mis on tavakasutajatele raskesti kättesaadavad.

Uurisime, millistest ilukirjanduslikest ning aimekirjanduslikest teostest võib pärineda tänapäeva inimese informatsioon Taevaskoja Emalätte kohta. Tartu Oskar Lutsu nimeline Linnaraamatukogu andmebaasis leiab otsinguga Taevaskoja kohta informatsiooni vaid üheksas raamatus, mis on ilmunud aastail 1940-2001 ja mis on Eesti tavakodanikule kõige kättesaadavamad.

Kõige põhjalikum teave on Jaan Vahtra ja Aleksander Ivaski turismikogumikus "Taevaskoda ja Valgemetsa" (Vahtra \& Ivask 1940), kus on enim kohapärimust Väikese Taevaskoja ja selle koobaste kohta, selle on kirjutanud otseselt Taevaskojas elavad ja sealset maastiku hästi tundvad inimesed. Eesti okupatsiooni eel koostatud raamat kirjeldab Taevaskoja ümbruse inimeste eluolu 20. sajandi esimesel poolel.

Hea ülevaade on ka Eerik Kumari "Ahja jõe ürgorg” (Kumari 1972), mis osaliselt toetudes eelmisele raamatule annab ülevaate Väikese Taevaskoja ajaloost ja 20. sajandi teise poole eluolust selles piirkonnas ning kirjeldab turismikoormuse suurenemisel tekkinud probleeme ja varinguohtlikku olukorda.

Rahvajuttude poolest on informatiivseim Heino Raieste "Taevaskoda" (Raieste 1982).

Ülo Heinsalu "Eesti NSV koopad" annab ülevaate koopa mõõtmetest, allikast ja sealt leiab ka muistendi Neitsikoopa kohta (Heinsalu 1978).

Taevaskoja Emalätte varingueelne situatsioon on täpselt fikseeritud Kristel Vilbaste raamatus "Eesti allikad" (Vilbaste 2013).

Üks intervjueeritav mainis rahvajuttude infoallikana ka Lemming ja Ilse Rootsmäe "Võnnu kihelkonna kohanimed ja minevik" käsikirja lugemist Eesti Kirjandusmuuseumi arhiivis 1980. aastatel, käsikiri ilmus trükisena alles 2016. aastal (Rootsmäe \& Rootsmäe 2016). Rootsmäed paigutavad mitmed erinevad kaldalõigud üldnime Väike-Taevaskoda alla, nii on erinevad kaljud ja nende koopad omandanud sarnase rahvapärimuse, ilmselt on jutumotiivid rahva suus rännanud ühest koopast teise.

\section{Taust: Taevaskoja Emaläte}

Taevaskoja Emaläte asub praegu Põlvamaal, Põlva vallas, Ahja jõe ääres, vanasti Võnnu ja Põlva kihelkonna piiril, Taevaskojas, täpsemalt Väikeses Taevasko- 
jas, kihelkonnapiir jookseb Emalättest paarisaja meetri kauguselt, 20. sajandi alguses viis sealt üle Ahja jõe sild. Emaläte on Taevaskoja suurim allikas, ta asub sajakonna meetri kaugusel põhja pool teisest olulisest allikast, Neitsikoopa Kuldlättest, mille vooluhulk on küll poole väiksem. Emalätet nimetati vanasti ka Puiga lätteks lähedal asunud talu järgi.

Allikas asub kümne meetri kõrguses devoni liivakivipaljandis Ahjajõe paremas kaldas. Väikest Taevaskoda nimetatakse ka Suurkaljuks, Alliku kaljuks, kuna kalju all asub suures koopas allikas (Kiviallikas) (Rootsmäe \& Rootsmäe 2016).

Allika vooluhulk oli enne varingut Ülo Heinsalu andmete järgi 4-4,5 l/s, vee temperatuur 5-6 kraadi, vesi on hästi selge, puhas ja hea maitsega (Heinsalu 1978). Praegu on allikaoja vesi orgaanikarikas ja kõrvalmaiguga, sest varingukoha kallastest vajub aegajalt sisse huumusrikas muld. Puhast vett saab võtta ojast otse koopast, mille juurde minek on ohtlik ja keelatud.

Emalätte koobas koosnes enne varingut Heinsalu mõõtmiste järgi kahest osast. Esiosa kujutas grotti laiusega kuni 8 meetrit ja kõrgusega suudmes ligi 3 meetrit. Püsti sai koopas edasi minna 5-6 meetrit, seejärel küürutades veel 3 meetrit. Kaheksa meetri kaugusel koopasuust algas tunnelilaadne koopa "saba" pikkusega 5 meetrit, mille lõpust algas allikaoja. Alguses oli tunnel 0,7 meetrit lai ja 0,6 meetrit kõrge, keskosas see laienes ja kõrgenes kuni 1 meetrini, lõpus aga muutus ligipääsmatult kitsaks. Sisse varises koopa 5-6 meetri pikkune esiosa, tagumine osa on alles.

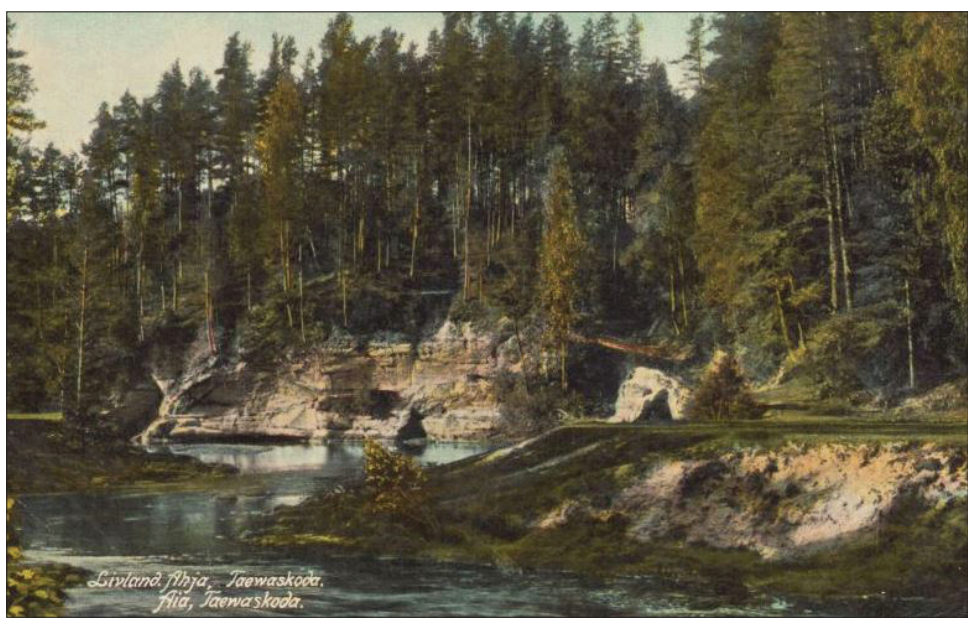

Foto 1. Taevaskoda 1900. aastate alguses. Väikese Taevaskoja paljand, millest voolab välja Emaläte, on 19. sajandi lõpul ulatunud Ahja jõe kaldani, kuid taganenud samm-sammult varingute toimel. Suuremaid varinguid on olnud vähemalt kolm. Vana piltpostkaart. 


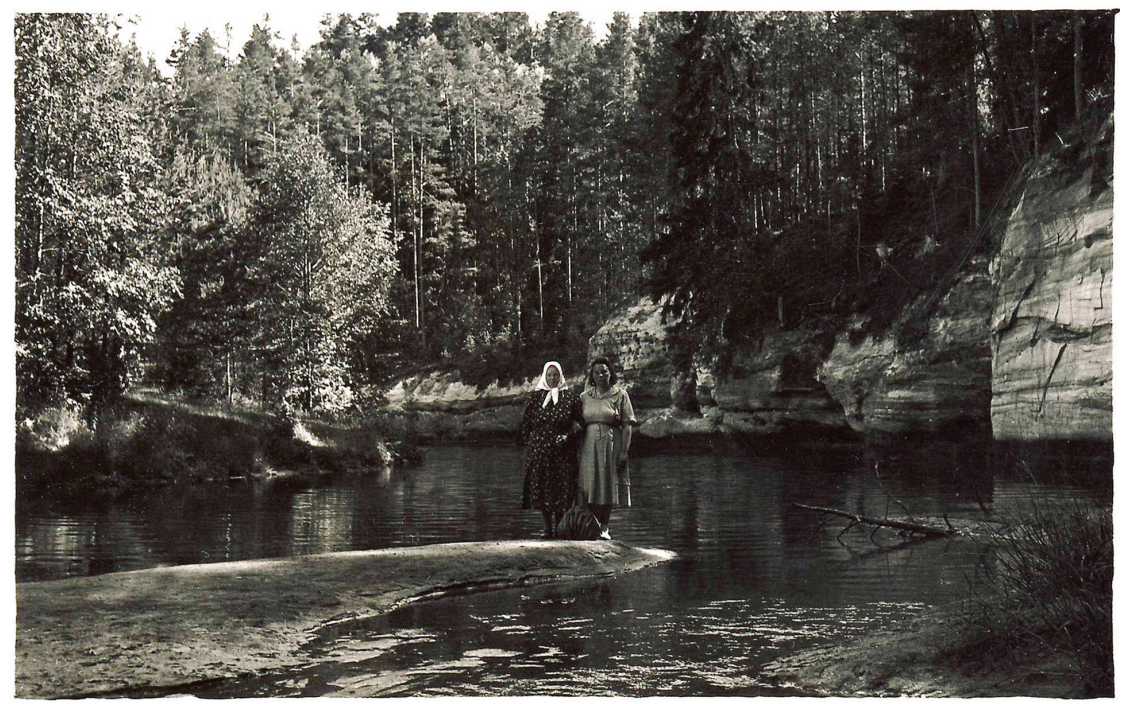

Foto 2. Emalätte koopa varingujärgne liivakeel Ahja jões 1930. aastatel. Tollal muutus turismikoormus nii suureks, et vana looduslik olek oli pidevas muutumises. 1960. aastatel toimunud väiksemate varingute järel toodi algselt üle koopalae kulgenud matkarada Emalätte koopa ette ja rajati trepp, mis viis vasakult poolt Emalätte ja Neitsikoopa vahelt Väikese Taevaskoja kaljule. Arhiivifoto.

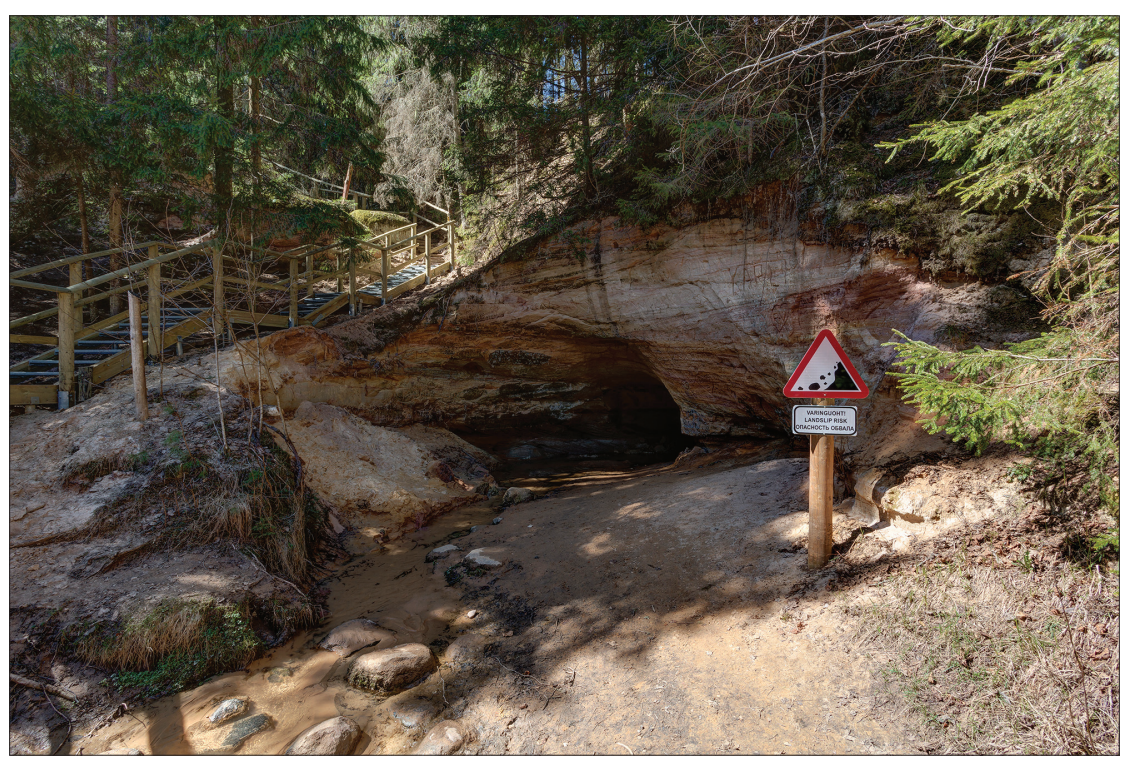

Foto 3. Taevaskoja Emalätte koobas vahetult enne varingut. Urmas Tartese foto 2013. 
Vanade piltide võrdlemisel nähtub, et Väikese Taevaskoja paljand, millest voolab välja Emalätte koobas, on 19. sajandi lõpul ulatunud Ahja jõe kaldani, kuid taganenud samm-sammult varingute toimel. Suuremaid varinguid on olnud vähemalt kolm. 1930. aastal oli allika lähikonnas Ahja jões pikem liivakeel. 1960. aastatel toimunud väiksemate varingute järel toodi algselt üle koopalae kulgenud matkarada Emalätte koopa ette ja rajati trepp, mis viis vasakult poolt Emalätte ja Neitsikoopa vahelt Väikese Taevaskoja kaljule. Emalätte koopalael filmiti 1969. aasta varakevadest hilissügiseni Tallinnfilmi "Viimset reliikviat", koopalael sõideti suurte autodega ja liivakiviseintelt raiuti labidatega seintesse kraabitud kirjad. Filmivõtete paigaks olnud vasakpoolne kaljunukk ja koopavõlv varisesid 1970. aastate lõpul ja allavarisenud liiv teisaldati praeguse rippsilla mademele.

Viimane varing toimus 2013. aasta 27. juunil õhtul. Ain Eriku suulistel andmetel viibis piirkonnas parasjagu ekskursioon, kes oli kuulnud, kuidas "Emaläte kummalist häält tehes nagu maavärinal sisse kukkus". Tollane metsaülem hindas vajalikuks koopalaelt suuri puid vähemaks raiuda, kuid see jäeti tegemata, kartes rahva pahameelt, et pühapaigas puid raiutakse.

Foto 4. Taevaskoja Emaläte pärast varingut 2013. aasta lõpus. Sisse on varisenud esimene koopaosa, tagumine 0,7 meetrit laiune ja 0,6 meetri kõrgune tunnel on alles. Kristel Vilbaste foto 2013.

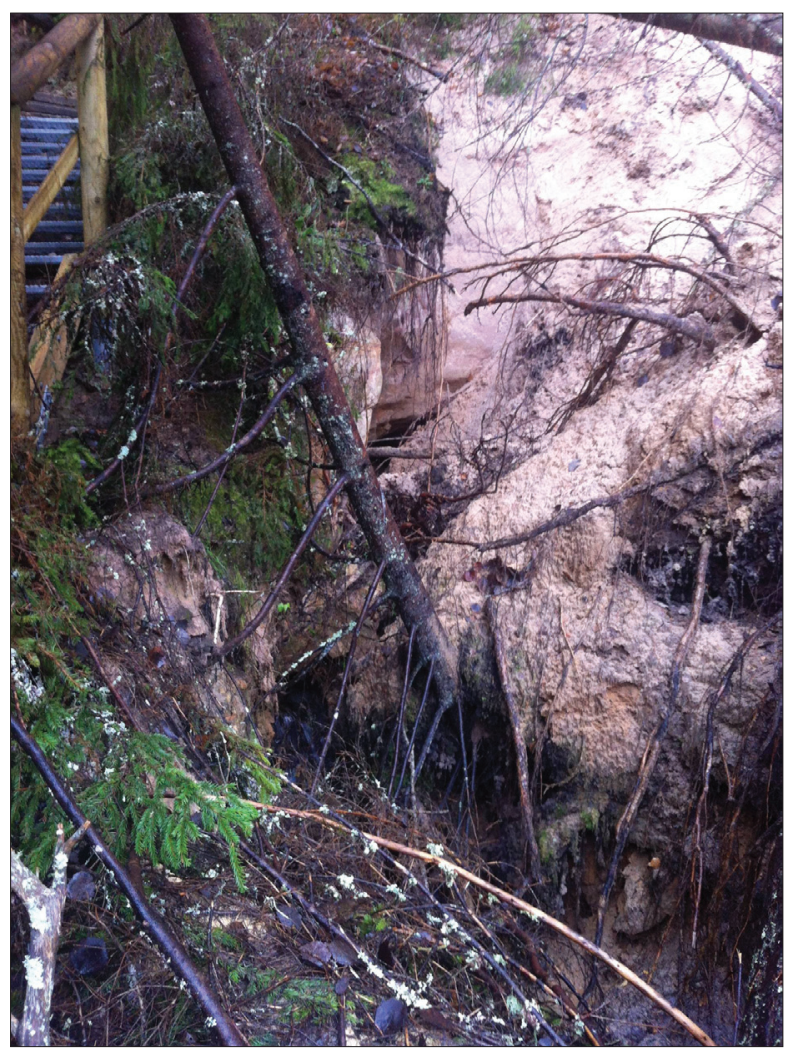




\section{Lühiajalugu: Emalätte ümbruse inimasustusest ja keskkonnakoormusest}

Taevaskoda on inimmõju piirkonnas olnud umbes 500 aastat, esimest Tikuta vesiveskit sealkandis mainitakse 1582. aastast (Raieste 1981).

Taevaskoja allikakoopaid mainiti esmakordselt 17.-18. sajandil, Kelchi kroonikas on kirjas, et “...Suur-Taevaskoja kaljus, veepinnast mitme jala kõrgusel olnud kitsas lõhe, millest inimene vaevalt läbi mahtunud. See sissekäik avanenud avarasse ruumi ja siit edasi kolme kambrisse" (Kumari 1972).

Need koopad olid veel 19. sajandil Valgesoo külaelanike teatel alles. Koopaallikate üks enim levinud muistend on koobastest algavate salakäikude ulatumine mõnda suuremasse linna või keskusse, sellised pikad koopad viitavad otseselt nende allikatetekkelisele päritolule. Sageli sisaldub sellises pärimusteates veel lugu, kuidas lind (part, hani vm), jänes või ese (pesukurikas) lastakse vette ja see tuleb välja hoopis kaugemal (Remmel 2014) või pannakse allikasse lastud köie otsa verine loomapea. Analoogsed pärimusteated on ka Taevaskojast.

Ahja jõe kaldal Valgesoo küla karjamaal nn. Pikaniidu käärus olla vana ohverdamise koht. Koht on lääne poole kerkival jõenõlvakul. Sihis $140^{\circ}-320^{\circ} 62$ sammu pikk, 35 sammu lai. Koha keskel paistab maast grupp moräänkivirahnusi. Leidustest ei teata. Koht ikke lage olnud, kadaka põesaline. Üle jõe teinepoolt Põlva kihelkonda, sest olla leitud 20 aasta eest vaskvöö, prees ja vaskraha.

Üldse annab sellel kohal Ahja jõgi oma tujukate käärudega loodusliselt väga ilusa koha. Järskused mäenõlvakud vahelduvad orgudega, saavutud kevadvetest. Valgesoo küla uhkuseks on ta Taevaskoda. Taevaskoja nimeline koht on väga järsk 18-20 meetri kõrgune devoni punase liivakivi kallas. Samas läheduses on teine samalaadiline koht Väike Taevaskoda. Kallas on poolkumer, millelt hääl vastu kajab, sellest vist küll koja nimi. Kaldas on koopaid, millest allikad jõkke nirisevad. Koha vaatamise väärtust täiendavad hulk legenda. Ühest, nimelt Vanakivi koopast, minna tee Kiievi, teise teisendi järel Riiga. Korra lasknud karjapoisid oina köiega auku, välja tõmmates olnud ainult sarved köie otsas. Ühes teises koopas olla tüdrukut ómblemas nähtud. Mehed läinud kord koopa, näinud seal väikest järve, mille keskel ohvrikivi ohvriga seisnud. Mehed põgenenud ja pärast vajunud see koopasuu kinni. Ka põrgu viia teed koopast, sisse võib küll vaadata, aga kaugemale minnes juhtuda õnnetus: kas tabada kurdiks, pimedaks või koguni hullumeelseks jäämine. Ka olla kord kirik mäkke vajunud. Mõnelt poolt peetakse kõrget kallast ohvrikohaks. 
Taevaskoja juures jões on kaunis suur ümargune kivi, see olla ohvrikivi ja ülevalt kaldalt jõkke langenud. Nü̈̈d istuda näkineiu õhtuti kivil ja silida kuldkammiga juust. Kalju vahelt immitsevaist lätteist on silmaarstimiseks vett toodud.

Valgesoo küla Taevaskoja nimelise koha kohta olla ajaloolisi andmeid G. Kelchil - Liefländische Historia's.

Taevaskoda on Põlva kihelkonna päralt. (E 52952/2a < Võnnu khk - Alice Karu (?). Võnnu khk, Ahja vald.)

Taevaskuast räägitäs, et kuupas olevat peni või verine lambapää irmutuses, et sinna sisse ei lä̈ä. Kiäki oll lännu sinna oonde. Kiäki oll sinna sisse lännu, nü̈̈r takan, et peräst tõmmatas tagasi, aga tõmmatu nü̈̈r tagasi ja verine oinapää otsan. Es ole inimest olluki.

(RKM II 208, 332/3 (3) < Põlva khk, Valgesoo k, Järvemäe t - Erna Tampere $<$ Samuel Kolsar, 85 a (1966).)

Taevaskuan om Emäläte, suurõmb läte Väikesen-Taevaskuan. Ma ole ka sääl kooban käänuq. Siist pidinuq Riia liina ala minemä koobas väl'lä. Üt'skõrd hagijas jänesega lännuvaq siist Riia liina ala vällä.

(RKM II 208, 153/4 (16) < Põlva khk, Koiola v, Eoste k - E. Tampere $<$ Joosep Kaha, 70 a (1966).)

Sõdade ajal on Taevaskoja koopad olnud varjupaigaks, mis pakkus üheaegselt varju ja joogivett, pelgukoobaste või pagukoobastena nimetatakse Väikese Taevaskoja koopaid ka Põhjasõja ajast, mil osad inimesed põgenesid, osad peitsid end koobastesse (Kumari 1972).

Rootsmäed kirjeldavad, et Väikese Taevaskoja allikatel pesid vanasti naised pesu, seega puudus juba 19. sajandi lõpul sel looduslikul pühapaigal algne religioosne tähendus ja paik oli igapäevaselt kasutatav argitoimingutes.

Varasemast religioossest kasutusest on vaid mõned kaudsed teated, sh ülaltoodud teade ühes allikakoopas paiknenud ohvrikivist. Rohkem leidub viiteid kõikide Taevaskoja allikate tervistavale toimele, peamiselt silmade ravimisel. Tänapäeval infotahvlitele kinnitatud pärimust naiste käima peale saamistest arhiiviteadetes ei leidu, kuid seda kinnitas ühes intervjuus hiljem kohalik elanik, väites, et oli seda oma vanaemalt kuulnud.

Esimesed talud Taevaskoja ümbruskonnas müüdi päriseks 1868. aastal. 20. sajandi alguse eluolu Taevaskojas on kirjeldanud August Gailit novellikogumikus "Ristisõitjad" novellis "Taevaskoja asunik" (Gailit 1927).

Kuni 20. sajandini polnud inimeste tegevus Ahja jõe ürgorus ohuks selle ala loodusele ja maastikule (Kumari 1972). Metsast varusid inimesed puitu ehituseks ja kütteks, marju ja seeni toiduks, seal on karjatatud ka loomi. Ahja jõgi 
oma rohkete vesiveskitega on võimaldanud vilja jahvatada ja laudu saagida, jõest on püütud kala ja vähki. Jõeorg oma Taevaskodadega oli kogunemiskohaks nii rahvakalendri tähtpäevadel kui ka usukommete täitmisel.

20. sajandi alguse tehnikarevolutsioon hakkas aga oluliselt muutma Ahja jõe ürgoru maastikku, varem peaaegu inimtühja paika tõi olulise pöörde1920. aastate teise poolel alanud Tartu-Petseri raudtee ehitamine. 1931. aastal sai see valmis ja anti ekspluatatsiooni, 1932. aastal pandi alus Valgemetsa suvituskohale. Tartu rahvas, kes siiani oli tundnud suurt puudust suvituskohtadest, sai suurepärase võimaluse kinnisvaraarenduseks. Tõsist kahju tekitasid huvirongidega kohalesõitvad inimesed, keda ei huvitanud sugugi Taevaskoja kaunis loodus, mille tundmaõppimisega ei osanud või ei tahtnud huvirongide organiseerijad tegeleda. Taevaskoda muutus peopaigaks, sellest ajast pärinevad ka rahvajutud, mis esimest korda kirjeldavad liivakivisse nimede kraapimist ja selle taunimist.

\section{Jaaniööl}

Juba vanasti olevat suure kalju sisse kraabitud nimesid sedamoodi, et keegi lasknud enese pika köiega kõrgelt alla ja kratsinud siis nime.

Kord olevat aga kaks noormeest lubanud kratsida jaaniööl suure nime kalju sisse.

Üks lasknudki enese köiega alla, kuna teine hoidnud ülal köie otsa. Äkki muutunud köis nii raskeks, et hoidja ei olevat enam jõudnud pida$d a$. Sidunud siis suure rutuga köie otsa ümber puu ja plaganud suure hirmuga koju. Kui järgmisel päeval vaatama mindud, leitud köie otsas rippumas vaid verine härja pea. Teine noormees jäänud aga jäädavalt kadunuks. (Vahtra \& Ivask 1940.)

Nõukogude ajal lisandusid rongiühendusele ka bussiekskursioonid, lisaks organiseerimata külastajate järjest suurenevale kokkuvoolule hakkasid Põlva rajooni organisatsioonid korraldama seal mitmesuguseid massiüritusi - laulupäevi, jaaniõhtuid, tuletõrjujate pidusid, spordivõistlusi, lõpuks ületas turistide hulk Taevaskoja taluvusvõime.

Peaaegu igal pühapäeval leidis aset mõni rahvarohke üritus. Need olid varustatud rikkalike einelaudadega, milles ei puudunud ka alkohoolsed joogid. Ahja jõe ürgoru loodustempel oli muudetud pillerkaaritamise platsiks, kus nimetähti täiskritseldatud kaljud, murtud puuoksad, ajutised ööbimislehtlad - jõekallaste rüüste tunnistajad, loendamatud lõkkeasemed haljal murul ja rämpsu täis põõsastikud ning jõepõhi enam mitte millegiga ei meenutanud vanade eestlaste pühakoda, mis puutumatuna oli hoitud põlvest põlve. (Kumari 1972.) 
1957. aastal moodustati Taevaskodade kaitseks Eesti NSV looduskaitseseaduse alusel Ministrite Nõukogu määrusega Ahja jõe ürgoru maastikukaitseala, kaitse korraldamise eeskirjad kinnitati 1959. aasta aprillikuus. Kaaluti isegi täielikku külastuskeeldu, ametisse võeti valvepersonal, uuematesse rahvajuttudesse on jõudnud looduskaitsevalvur Kurvits.

Eerik Kumari hakkas Taevaskoja kaljuseinte täiskritseldamise tõkestamiseks propageerima täielikku kaljudele ja puudele nimede kirjutamise keeldu, mis ka lõpuks looduskaitseseadusega kehtestati ja mis näitena jõudis ka kooliõpikutesse.

1969. aasta varakevadest kuni hilissügiseni filmiti Emalätte läheduses "Viimset reliikviat". Maastikku ja ümbrust kujundati vastavalt vajadusele ümber üsna toorelt: devoni liivakivisse sajandi jooksul kraabitud kirjad raiuti seintelt labidaga maha, suurte autodega toodi Väikese Taevaskoja kaljule tehnika. ${ }^{4}$

Taasiseseisvumise järel hakkas kaitseala valitsema keskkonnateenistus, ala kujunes taas populaarseks turismiobjektiks. Külastajaid loendati mõnel aastal kuni 50 000. Samuti tähtsustus taas Emalätte koobas loodusliku pühapaigana. Koopasse pandi küünlaid, ümbruse puudele riputati linte, toimusid näiteks maausuliste varrud, aga ka muud religioossed talitused.

Kaitseala korrastustööd läksid 2000. aastate keskpaigas üle Riigimetsa Majandamise Keskusele (RMK). Toimusid esimesed väikesed varingud, Emalätte juurde paigaldati hoiatusmärk "Varinguoht".

2012. aasta teisel poolel algasid Taevaskojas RMK hankena Taevaskoja matkaradade ehitustööd. Materjali veeti laiali ATV-ga ja Emalätte koopa vasakusse nõlva valati betoonist trepikäsipuude alused.

27. juuni õhtupoolikul 2013 varises koobas sisse. Esimesel varingujärgsel päeval avati labidaga allika veevool, kuigi hiljem räägiti, et allikas ise leidis läbipääsu.

Emalätte varingu järel peeti arvukalt koosolekuid, kus tuliselt polemiseeriti, mida ja kuidas edasi teha. Esimene koosolek kaitseala hooldustööde korraldaja RMK ja kaitseala valitseja Keskkonnaameti töötajate vahel toimus juba 1. juulil 2013, neli päeva pärast varingut. Kaks kuud hiljem valmis Keskkonnaameti ekspertarvamus, milles anti juhis, et "paljandi esise ala võiks varisenud puudest ja puujuurtest koristada. Töö tuleb teha käsitsi. Liivast võiks puhastada ka endise voolusängi”. Ekspertarvamusena kajastati teadet, et koopa varing oli looduskatastroof ja looduslik pühapaik tuleb kaitsealal jätta looduslikku seisu. Väideti, et liivakihi eemaldamisel võib varisemine jätkuda.

Renoveerimistööd algasid 2014. aasta aprillis, kui Keskkonnaameti kutsel kogunesid koosolekule Keskkonnainspektsiooni, RMK, Taarausuliste ja Maausuliste Maavalla Koja ja Taevaskoja küla esindajad, koosolekul otsustati korraldada Emalätte puhastamise talgud 1. mail 2014. 
Külvanem Ahti Bleive kirjeldab talguid Põlva Teatajas 27. mail avaldatud artiklis:

Kohal olid Keskkonnaameti, Keskkonnainspektsiooni, Riigimetsa Majandamise Keskuse, Taarausuliste ja Maausuliste Maavalla Koja ja Taevaskoja küla esindajad. Langenud puude eemaldamiseks ja tükeldamiseks olid kohalikud külaelanikud välja otsinud juba unustuse hõlma langenud kahemehesaed, mis kusagil kuurinurkades vaikselt roostet kogusid. Tartust leiti eelnevalt ka ettevõte, kus saed endale teravamad hambad said. Kahemehesaed võeti kasutusse eelkõige just seetõttu, et mootorsaega mitte tekitada vibratsiooni ja mitte reostada allikat, mida pühaks peetakse. Suuremad langenud puud, mis juba eelmisel aastal olid lühemaks saetud, tehti veelgi lühemaks, sest nendest olid tekkinud omamoodi sillad, mis võimaldasid turnida ja liivahunnikule ronida. Mõned väiksemad puud eemaldati täielikult. Samuti korjati ära kõik lahtised juured ja oksad.

\section{Suuline pärimus versus kirjutatud seadus}

2016. aasta sügisel läbiviidud intervjuude ajaks oli esialgne opositsioon vähenenud. Kõik vaidluses osalenud osapooled aktsepteerisid otsust, kuid olid jäänud siiski oma arvamuse juurde, kohalik kogukond käis salaja allakukkunud puude juuri saagimas, samuti eemaldasid liiva nii kohalikud inimesed kui ka külastajad. Ahja jões oli varisenud liivast pikk liivakeel nagu 1930. aastatel aastatel, see ulatus jõe keskpaigani.

Küsitletavateks valisime sel ajahetkel soovitatu põhjal diskussioonis aktiivselt osalenud inimesed. Nendeks olid praegu Tartus elav õpetaja, kelle kolm eelnevat põlve on elanud Taevaskojas $(59, \mathrm{~N})$; külavanem $(49, \mathrm{M})$; pühapaikade uurija (47, M); looduskaitseorganisatsiooni esindaja (53, M) ja RMK piirkonnajuht $(39, \mathrm{M})$. Ühe intervjuu viisime läbi otse Taevaskoja Emalätte juures, teised Tartus.

\section{Suuline pärimus on elujõuline}

Intervjuudes püüdsime esmalt välja selgitada intervjueeritava tausta ja Taevaskoja Emalättega seotuse põhjused ning selle paiga pärimuse tundmise allikad ja mahu.

Intervjueeritavate vastustest selgub, et kõige rohkem tunneb Taevaskoja muistendeid ja kohalikku pärimust ning oskab konkreetseid lugusid rääkida 
neljanda põlve kohalik elanik, seejärel külavanem, kes on küll Taevaskojas elanud sünnist saadik, kuid tema vanemad on sinna tööle läinud, siis pühapaikade uurija, seejärel RMK piirkonnajuht ja kõige vähem looduskaitseorganisatsiooni esindaja.

Paremini on pärimuslood meelde jäänud sagedamini kohapeal elanud inimestele, kellel on otsene suhe maastikuga. Nad on need pärinud suuliselt oma vanematelt ja vanavanematelt. Näited.

Külavanem, 49, M:

Lapsepõlves kuulsime poistega sellist lugu, et kui minna Emalättesse hästi sügavale sisse, siis pidi avarduma, et taga on kusagil suur koobas. Me poistega otsisime isegi taskulambi, ja käisime vaatamas, mis seal on, aga me ei jõudnud eriti kaugele, sest see vesi oli nii külm. Me pidime lõpus kõhuli laskuma, et oja pidi üles minna, aga me ei leidnud küll mingit avardumist. Aga neid lugusid räägitakse.

Aga ohvrikivi on siin üleval, need kaks asja lähevad täiesti omavahel kokku.

Koopas käiakse ande pigem praegu panemas. Ohvriannid pandi pigem kivi juurde. Praegu käiakse jõulude ajal teeküünlaid panemas, see on visuaalselt ilus, peaasi, et pärast need ümbrised ära korjatakse. Münte pandi pigem kivile, aga need korjati ka alati ära. 1970-80ndatel neid kopikaid oli. Suuremas koguses münte ei olnud.

Paelad on suhteliselt hiljaaegu tekkinud. Enne varingut ei olnud. See on uus asi, sellist kommet siin ei ole olnud. See on pigem Maavalla koja tegevus.

Pühapaikade uurija, 47, M:

See on terviseallikas muidugi. Pärimust on küll palju rohkem Neitsikoopast, Kuldallikast mis seal on. Selle kolina kuulamas käimine kevadpühadel. Sellest on palju kõneldud ja keeld, et ei tohi sinna minna mingil juhul. Neitsilätte allikavee kasutamisest on väga vähe juttu. Mainitud on, et kõik on terviseallikad, mis sealt kaljust välja voolavad. Kusagil on nendes materjalides. Seda materjali on nii palju, mul on raske eristada, $k a$ ise kuuldud jutud. Aga üldmulje on see, et Neitsikoopa allika kasutamist on mainitud, aga juttu on väga vähe, et sealt on vett võetud. Aga Emalätte puhul on see tavaline, et sealt käiakse vett toomas, see on loogiline, sest et on kuival maal, Neitsikoopasse peab minema üle jõe. 1940. aastal ilmunud Valgemetsa, Taevaskoja, nemad on kasutanud pärimuslugusid. Seal on unikaalseid teateid. Mida mujal ei ole ilmunud.

See mis kirja on saanud, on üsna juhuslik. Emalätte puhul seda laialt tuntud pärimust ei ole. Taevaskoda on ise küllaltki salajane, see 
on olnud lähikülade pühapaik, uuemate andmete järgi. 20. sajandi algul on tuhanded inimesed seal käinud jaanipäeva pidamas. Inimesed on meenutanud intervjuudes. Need olid lähikonna inimesed.

Pärimuslugusid ja raamatuid lugedes lood meelde ei jää, oluline on nende edasirääkimine konkreetsel maastikul. Näited.

Õpetaja, neljanda põlvkonna kohalik elanik, 59, N:

Neitsikoopas olen lapsena käinud. Sealt voolab välja päris suur allikas, sellest muidugi räägitakse, et see läheb Riiga välja. Ma ei käinud väga kaugel ja ei tea, kas ta hargneb kolmeks. Aga üks asi on seal see, miks seal ei käidud, on uskumine, et seal ei tohi käia, kes üldse võib sinna sisse minna, noh, kuna ta on Neitsikoobas, siis tõesti ainult sü̈̈ta neitsid, teistega olla igasuguseid koledaid asju juhtunud, küll ikka seal inimesed päris ära kadunud, meesterahvad, kes olevat läinud sinna varandusi otsima, mis seal ka olevat. Või siis hirmulugusid, et keegi meesterahvas oli ikka pika köiega läinud ja pärast tõmmatud välja ainult verine lamba-või sikupea. Vanaema nendest hirmsatest lugudest küll ei rääkinud, tema rääkis pigem seda, et ei sobi käia, et seal elavad nende jõkke uppunud neitsite hinged. Seda rääkis, et seal elasid vette uppunud neitsite hinged.

Mina käisin koopas üksi, vanaemaga ei käinud, sinna pidi läbi vee minema. Seal oli pühaduse tunne. Ma olen seal käinud üks neli korda üldse. Meile öeldi Emalätte kohtagi, et jalgupidi vees ei sobi käia. Et see on püha vesi ikkagi.

Emalätte vesi on hea vesi ja aitab väga paljude hädade vastu. Neid hädasid oli ikka väga palju, ei ole ainult silmaläte. Niipalju kui ma neid jutte mäletan, siis ta pidi aitama ka emaks saada. Seda rääkis ka vanaema. Kui oli probleeme või muresid, siis tuli kasutada, aga mida tegema pidi, nii täpselt vanaema ei rääkinud.

Vett me tõime kogu aeg sealt. See värske puhas allikavesi sealt. Meil on üks selline naljakas lugu sealt. Vanaema ehitatud maja juures ei olnud kaevu, me tõimegi joogivett sealt, pesuvett korjasime vihmaveest, joogivee tõime allikast. Küll toodi ka vanaisa talust käruga, talvel ka kelguga. Talvel on allikal raske käia, kui rohkem vett vaja oli, siis toodi ikkagi kaevust. Kaevu eesti ajal ei tehtud, vene ajal ei saanud luba, ei antud nii sügava kaevu puurimiseks luba.

Vett viisime nii palju kui vaja oli. Allikalkäimine suvel oli peaaegu igapäevane tegevus ja kui ma tudeng olin, siis meil oli kombeks ka hommikuti käia allikal silmi pesemas. Hommikune silmapesu oli lihtsalt mõnus, 300 meetrit on see allikas majast. Hommikune tee oli värskest veest. 


\section{Turism destabiliseerib loodusliku pühapaiga}

Nii nagu eelpool kirjutatud, hakkas turismi osakaal Taevaskojas suurenema 20. sajandi kolmandal aastakümnel, kui raudteeühenduse loomisel muutus kauni maastikuga paik atraktiivseks lähilinnade elanike seas. Varem suhteliselt inimtühja paiga külastatavus kasvas hüppeliselt ja see trend on jätkunud käesoleva ajani. Mõnevõrra ootamatu oli paiga korrashoiu eest vastutava intervjueeritava teade, et paiga külastuskoormus, mis enne varingut niigi oli lubatu piiril, suurenes varingu järel poole võrra. Ta toob põhjenduseks meediakära loodusõnnetuse järel ja sellele järgnenud skandaalsed vaidlused: "Igaüks tahtis näha, mis siin juhtunud on ja kes on varingus süüdi."

Väga suure varieeruvusega olid vastused, miks toimus looduskatastroof pühapaigas, kas see oli inimtekkeline või loodusjõududest põhjustatud? Emalätte koopa sissekukkumise põhjuseks peetakse puude raskust koopalael, trepi aukude puurimisel tekkinud vibratsiooni, loodusliku protsessi, nimede ja küünlaaukude kraapimist kaljusse, ehitusmaterjali vedu teede rajamiseks, kohalikud elanikud viitavad RMK trepiehitusele, ülejäänud loetlevad looduslikke põhjuseid.

Küsimusele, kas koobas ja allikas tuleks avada ja varisenud paik "korda teha", vastati erinevalt. Kohalikud elanikud ja paika haldav inimene leidsid, et võiks taastada endise oleku, sest siis saavad inimesed sealt jälle vett. Pühapaikade uurija ja looduskaitseorganisatsiooni esindaja leidsid, et paik tuleks jätta looduslike protsesside kätte.

Paiga loodusliku taastumise hooleks jätta soovivad intervjueeritavad ei külasta Emalätet kuigi sageli, vaid korra või paar aastas. Kohapeal elav inimene ja Emalätte lähedalt pärit inimene aga peaaegu iga nädal, nemad on seda teinud ka kogu elu. Nende soov allikaesine puhastada ja koobas renoveerida on loomulik, sest nad kasutavad allika vett joogiks ja ka raviveena. Vähem piirkonnas käivad inimesed kasutavad seda töökohustuse, religioosse põhjuse või hobi tõttu.

Selgus, et diskusioonis osalenud ja milleski justkui kokku leppinud osapooled ei tea, mida on teine osapool allika juures praeguseks teinud. Inimesed, kes paika kuigi sageli ei külasta, arvasid, et koopa avanemise ja allikavee läbimurde puhul on tegemist loodusliku protsessiga, kuid küsitlemisel selgus, et paika on viimase kolme aasta jooksul väga oluliselt inimjõul muudetud. Millest võib teha järelduse, et looduslikke pühapaikasid on võimalik korrastada nii, et enamik inimesi sellest aru ei saa. See annab huvitava viite ka teiste Eesti religioossete allikate pärimusteadetes sisalduva teabe kohta, et allikaid on alati puhastatud. See on mõnevõrra erinev teiste hiite teadetest, kus "ei lubata isegi oksa murda või puud raiuda". Religioossete allikate kasutamise ainus eesmärk ei 
ole läbi viia usurituaale kaunis ja väekas paigas, oluline on ka puhta joogivee kättesaadavus. Selle tagamiseks on pühasid allikaid aegajalt korrastatud, nii et looduslik tasakaal ja vee puhtus säiliksid. Sellest tulenevalt võiks oletada, et koopaallikate sissevarisemise järel varingumaterjali eemaldamine ei kahjustaks oluliselt inimeste usulisi tõekspidamisi ega ka keskkonda.

Vastuoluline perspektiiv tekib maastikuobjekti väärtuse erinevatest hinnangutest, ühel juhul hinnatakse Taevaskoja Emalätet pärandkultuuri objektina, millel on praktiline kasutus ning see on ka rekreatsioonipaik, kus käiakse meelerahu saamas, mis on kaudselt sarnane varasema religioosse objekti, hiie, väärtustega. Teisel juhul vaadeldakse Emalätet kaitstava objektina, mille väärtusi saab säilitada vaid ilma igasuguse edasise inimmõjuta. Kohaga tugevalt seotud intervjueeritavate ja välitöödel küsitletud inimeste arvates ei saa aga inimmõju Emalätte, mis on kogu Eestis tuntud turismiobjekt ja eriti kauni maastikuga looduslik pühapaik, puhul niikuinii vältida. Seega ei saa siin rakendada looduskaitseseadusest tulenevaid reegleid, et paik tuleb jätta looduslikule taastumisele.

Konkreetse objekti puhul tuleb lähtuda kohapealsest suulisest pärimusest, mitte rakendada looduslike pühapaikade eeskirju või kohaldada religioossele koopaallikale vajalikke taastamistöid.

\section{Emalätte taasväärtustamisest}

Viienda küsimusteblokiga uurisime loodusliku pühapaiga omandisuhet. Kellele kuulub looduslik pühapaik, seda nii erinevate usurühmituste, maakasutusvormide, kui ka keskkonnakaitse lõikes? Kellel peaks olema looduslike pühapaikade hooldamise õigus? Milline peaks olema Taevaskoja Emalätte taasväärtustamise tee ja mis on tema perspektiiv?

Kõik küsitletud tunnistasid, et tunnetavad paiga pühadust. See ei peitu vaid paiga ilus ja teistelt kuuldus. Küsimusele, kellele peaks kuuluma pühapaik, vastati, et see peab kuuluma Eesti rahvale. Küsimusele, kes peaks paiga heaolu eest seisma, ei osatud üheselt vastata. IUCN looduslike pühapaikade kaitse juhendi järgi (Wild \& McLeod 2008) on paiga staatuse üle otsustajateks selle eestkostjad, kelleks sobivad praeguste seaduslike ja kirjasõnast lähtuvate seaduslike valdajate asemel pigem kohaliku kogukonna esindajad, vahetu suulise pärimuse kandjad. 


\section{Kokkuvõte}

Püstitasime tööhüpoteesi, et suuline pärimus on keskkonnateadlikkuse representeerimisel reaalsituatsioonis efektiivsema toimega kui kirjalik pärimus. Selle kontrollimiseks pakkus võimaluse laialdast poleemikat tekitanud Taevaskoja Emalätte varing 27. juunil 2013. aastal ning sellele järgnenud diskussioon, kas ja kuidas varingu tagajärgi likvideerida, respekteerides loodusliku pühapaigaga seotud traditsioone ning erinevaid kasutajaid ja huvirühmi.

Kasutasime juhtumiuuringul poolstruktureeritud intervjuusid diskussiooni erinevate osapoolte esindajatega, kelleks olid: neljanda põlve Taevaskoja asukas, praegu Tartus elav õpetaja; külavanem; pühapaikade uurija; looduskaitseorganisatsiooni esindaja ja RMK piirkonnajuht.

Pärimuslugudes sisaldub juhis loodushoidlikuks käitumiseks ja keskkonnahoiuks, pühapaigaga seotud muistendites on mitmed keskkonnateadlikkust tõstvad keelud ja käsud ning hoiatused: allika äärest ei tohi liiva kraapida, Neitsilätte juurde võivad minna vaid ilmsüüta neitsid, jalgupidi ei tohi minna allikavette. Teiste allikate pärimusteadetes on ohtralt viiteid allikate reostamise ja tõkestamise keelust. Lugude kaudu õpetati kogukonna liikmetele pühapaikades käitumise kombeid, mis kaitsesid looduslikke pühapaikasid. Tänapäeval sätestatakse seda kirjapandud seaduste ja ametkondlike trahvimääradega. Siiski ei toimi see nii tõhusalt kui kogukondlik vahetu suuline pärimus.

Emalätte kaasuse põhjal saab rääkida keskkonnaproblemaatikast. Inimene tahab eksponeerida objekti, kuid sellega suureneb ökoloogiline jalajälg, mitmed olulised looduslikud pühapaigad on hävinud. Loodust ei saa sellistes paikades hoida keeldudega, pärimuslik loodushoid avaldub looduse pühakspidamise lugudes.

Religioossete rituaalide kõrval argielus olulise puhta joogivee kättesaadavuse tagamiseks on pühasid allikaid ikka aegajalt puhastatud ja korrastatud. Nii lähtus kohalik rahvas tegutsedes suulisest pärimusest, puhastas Emalätte allika ja näitas üles allikapärimusel põhinevat keskkonnateadlikkust.

\section{Kommentaarid}

1 Artikkel on seotud uurimisteemaga UT 3-2 "Kultuurimuutused: tähendusloome teoreetilised väljad ja mehhanismid".

2 "Taevaskojas sissevarisenud Emalätte saatus on jätkuvalt lahtine", Maaleht 12.11.2013 (http://maaleht.delfi.ee/news/maaleht/uudised/taevaskojas-sisse-varisenudemalatte-saatus-on-jatkuvalt-lahtine?id=67076920 - 23. jaanuar 2018); "Vangistatud vee mürin”, Kristel Vilbaste, Looduskalender, 17.10.2015 (www.looduskalender.ee/ node/25217 - 23. jaanuar 2018). 
3 Üks oluline intervjuu jäi tegemata intervjueeritava kõrge vanuse ja tervisliku seisundi tõttu, kuid ta andis olulist teavet allika ajaloo ja ka sissevarisemise põhjuste kohta, telefonivestlust ei dokumenteeritud, sest info kogunes intervjuu kokkuleppimise käigus.

4 See info pärineb intervjuudest.

\section{Allikad}

Intervjuud Emalätte taastamise diskussioonis osalenud inimestega, mis on autorite poolt salvestatud ja arhiveeritud.

\section{Kirjandus}

Bleive, Ahti 2014. Emalättest ja talgutest. Põlva Teataja, 27. mai, lk 7.

Bord, Janet 2006. Cures and Curses. Ritual and Cult at Holly Wells. Heart of Albion Press.

Cosgrove, Denis 2003. Landscape Ecology and Semiosis. Palang, Hannes \& Fry, Gary (toim). Landscape Interfaces. Cultural Heritage in Changing Landscapes. Dordrecht: Kluwer Academic Publishers, lk 15-20 (doi: 10.1007/978-94-017-0189-1_2).

Gailit, August 1927. Taevaskoja asunik. Ristisõitjad. Tartu: Loodus.

Harte, Jeremy 2008. English Holy Wells. A sourcebook. The ultimate source of intormation. Volume One plus CD of Volumes Two and Three. Heart of Albion Press.

Heinsalu, Ülo 1987. Eesti NSV koopad. Tallinn: Valgus.

Kaljundi, Linda \& Sooväli-Sepping, Helen 2014. Eesti maastiku ja mälu uurimise rajajooni. Kaljundi, Linda \& Sooväli-Sepping, Helen (koost). Maastik ja mälu. Pärandiloome arengujooni Eestis. Tallinn: Tallinna Ülikooli Kirjastus, lk 7-36.

Kaur, Egle \& Palang, Hannes 2005. Inimmõjuga maastikest. Maran, Timo \& Tüür, Kadri (toim). Eesti looduskultuur. Eesti Kultuuriloo ja Folkloristika Keskuse aastaraamat. Tartu: Eesti Kirjandusmuuseum, lk 363-378.

Kumari, Eerik 1972. Ahja jõe ürgorg. Tallinn: Eesti Raamat.

Kõivupuu, Marju 2014. Pärimus maastikul, maastik pärimuses. Hargla ja Kambja kihelkonna näitel. Kaljundi, Linda \& Sooväli-Sepping, Helen (koost). Maastik ja mälu. Pärandiloome arengujooni Eestis. Tallinn: Tallinna Ülikooli Kirjastus, lk 441-475.

Maaleht 2013 = Taevaskojas sissevarisenud Emalätte saatus on jätkuvalt lahtine. Maaleht.Delfi 12.11.2013 (http://maaleht.delfi.ee/news/maaleht/uudised/taevaskojassisse-varisenud-emalatte-saatus-on-jatkuvalt-lahtine?id=67076920 - 29. jaanuar 2018).

Raieste, Heino 1981. Taevaskoja. Tallinn: Eesti Raamat.

Rattue, James 2001. The Living Stream. Holy Wells in historical context. Boydell Press. 
Remmel, Mari-Ann 2007. Hiiepärimuse sõnum tänases Eestis: lähteandmeid ja tõlgendusvõimalusi. Valk, Heiki (toim). Looduslikud pühapaigad. Väärtused ja kaitse. Õpetatud Eesti Seltsi toimetised 36. Tartu: Tartu Ülikool, lk 239-257.

Remmel, Mari-Ann 2014. Veekogud Eesti ja Soome kohapärimuses. Valk, Heiki (koost). Muistis, koht ja pärimus II. Pärimus ja paigad. Muinasaja Teadus 26: 2. Tartu: Tartu Ülikool, lk 125-170.

Rootsmäe, Lemming \& Rootsmäe, Ilse 2016. Võnnu kihelkonna kohanimed ja minevik. Eesti Rahvaluule Arhiivi toimetused 34. Tartu: EKM Teaduskirjastus.

Siikala, Anna-Leena 2004. Kuuluvuspaigad: ajaloo taasloomine. Mäetagused 26, lk 53-68 (doi: 10.7592/MT2004.26.siikala).

Sooväli-Sepping, Helen 2016. Kultuurigeograafia. Tamm, Marek (koost \& toim). Humanitaarteaduste metodoloogia. Uusi väljavaateid. Tallinn: Tallinna Ülikooli Kirjastus, lk 170-186.

Svensson, Håkan (toim) 2012. Källor i Sverige. Stockholm: Sivart Förlag.

Tamla, Toomas 1985. Kultuslikud allikad Eestis. Tedre, Ülo (toim). Rahvasuust kirjapanekuni: Uurimusi rahvaluule proosaloomingust ja kogumisloost. Tallinn: Emakeele Selts, lk 122-146.

Vahtra, Jaan \& Ivask, Albert 1940. Taevaskoda ja Valgemetsa. Koguteos. Lõuna-Eesti monograafiad 1. Tartu: Noor-Eesti.

Vilbaste, Kristel 2013. Eesti allikad. Tallinn: Varrak.

Vilbaste, Kristel 2015. Vangistatud vee mürin. Looduskalender, 17.10.2015 (http://www. looduskalender.ee/node/25217?device=mobile -29 . jaanuar 2018).

Wild, Robert \& McLeod, Christopher (toim) 2008. Sacred Natural Sites: Guidelines for Protected Area Managers. Gland, Switzerland: IUCN.

\section{Summary}

\section{Orality and literacy in spring lore on the example of Emaläte at Taevaskoja}

\section{Kristel Vilbaste}

Postgraduate student, School of Humanities

Tallinn University, Estonia

kristel.vilbaste@gmail.com

\section{Mikk Sarv}

Folklorist, MA in educational sciences mikk@ilm.ee

Keywords: Emaläte at Taevaskoja, landscape discourse, landscape memory, revaluation of a sacred place, spring lore 
The working hypothesis of the article is that in a real life situation environmental awareness based on oral heritage is more appropriate than acting based on the knowledge of written heritage. An opportunity to check it out was provided by the collapse of the Emaläte (Mother's Spring) at Taevaskoja, southern Estonia, on 27 June 2013, and the subsequent discussion on whether and how to liquidate the consequences of the collapse, not losing respect for the natural sacred traditions of a variety of users and stakeholders associated with the place.

We used the case study method with semi-structured interviews conducted with representatives of various parties of the discussion: a school teacher whose family had lived at Taevaskoja for four generations, a village elder, a researcher of natural sacred places, a representative of a nature conservation organisation, and regional manager of the of State Forest Management Centre.

A large part of urban Estonians have obviously moved so far from folklore that it does not play any role in their life. But another part of the population still needs it.

Old stories include environmental behavioural guidelines concerned with sacred places and nature conservation. Legends associated with sacred places have a number of environmental awareness-raising restrictions, commands, and warnings: one should not scrape the sand next to the sacred spring, the Neitsiläte (Virgin's Spring) can be visited only by innocent virgins, one should not step into the spring. Other holy springs have abundant references to avoiding pollution and impoundment of the spring flow. Members of the community were taught through stories about behavioural habits in the holy places. Today, the behavioural regulations concerned with sacred places are written down in the laws and established penalty rates. However, it does not work as effectively as the immediate oral history in the community.

We can discuss environmental issues on the basis of the Emaläte case. The authorities want to expose the sacred objects to the public, but this increases the ecological footprint and may damage the object. The traditional nature conservancy manifests itself in the oral heritage - legends about sacred places.

None of the parties that participated in the discussion knew what others had done at the holy spring. Those who did not visit the place very often thought that everything that had happened after the collapse of the cave was a natural process. In fact, many people had been cleaning up the vicinity of the sacred spring for the past three years. What can be concluded is that natural sacred places can be put in order so that the majority of people do not even notice it. This provides an interesting reference to the information about other sacred springs in Estonia, which says that the springs must be regularly cleaned up. This is somewhat different from the reports on sacred groves, which state that "not even a branch could be allowed to cut from the trees". Sacred springs are not only meant for performing religious rituals at a beautiful place, but they need to be cleaned up and the water has to be accessible to visitors. To ensure this, the sacred springs were periodically cleaned, in order to keep their natural balance and to preserve the purity of the water. Consequently, one might conclude that, after the collapse of the cave of the Emaläte, the removal of the rubble from the collapsed cave should seriously undermine neither people's religious beliefs nor the environment. The local people who had acted according to their oral heritage and cleaned the spring again, had demonstrated environmental awareness based on traditional spring lore. 